\title{
ASSESSMENT OF BLENDED LEARNING EDUCATION MODEL: UPTAKE AND REASONS FOR ITS IMPLEMENTATION IN CONSTRUCTION EDUCATION
}

\author{
RAPHEAL ABIODUN OJELABI, ADEDEJI OLUSHOLA AFOLABI, IGNATIUS \\ OWOICHO OMUH, and PATIENCE FIKIYEMO TUNJI-OLAYENI \\ Dept of Building Technology, Covenant University, Ota, Nigeria
}

\begin{abstract}
The emergence and integration of information technology in modern age education training have changed the face of education across the globe. The need for the blend of information and communication technology tools in construction education training is of the high essence as it enhances students learning capacity through visuals and other means. Therefore, the study investigates the level of the blend of ICT with the traditional method of learning among lecturers within the built environment departments in Covenant University in Nigeria and reasons for its use were also examined. A survey method was adopted for the study; 125 structured questionnaires were administered to the randomly selected lecturers and 100 were retrieved. The data collected was analyzed with Mean item score, percentage, and Mann-Whitney U respectively. The result revealed that the adoption of the ICT tools, which include interactive whiteboards PowerPoint, a learning management system, and video clips among the lecturers is very high. The reasons attributed to its use is due to the visual platform it provides for the students while weblogs, web conferencing, and mobile phone were the lesser used tools. In conclusion, the study recommends that Covenant University management should increase the funding of ICT tools and also enhance the lecturers training in the use of blended learning style.
\end{abstract}

Keywords: ICT, Covenant University, Built environment, Nigeria.

\section{INTRODUCTION}

The $21^{\text {st }}$ century education system has taken a new dimension with the advent of information and communication technology (Afolabi et al. 2017). Buran and Evseeva (2015) asserted that the world has become digital and likewise the education process as a result of the introduction of ICT tools into modern education training. Matukhin and Zhitkova (2015) also affirmed the integration of technology in all areas of life including education in the modern age. It is evidenced from the foregoing that modern age awareness and adoption of information and communication technology is second-to-none. The integration of ICT tools into traditional educational space as birth a new model of education known as 'blended learning model'.

Blended learning according to Culatta (2011) is described as the merger of e-learning together with traditional face-to-face teaching aided by an instructor. Likewise, Mason and Rennie (2006) asserted that blended learning is the integration of online learning into the 
traditional model of education. The acceptance of the blended learning model in the modern age can be traced to the need for the integration of information and communication technology in all fields of human endeavors, in which the education field is not an exception. Tapscott (2008) however buttressed that the $21^{\text {st }}$ century students attitude towards information and communication technology tools have made the need for blended learning education model inevitable. Coiro (2003) further elucidate that blended learning model adoption is not an option in the modern age because literacy in education has been redefined beyond students' ability to read, write, learn, and comprehend; it also now includes students' ability to interact with technology. Undoubtedly, the students expected learning outcomes in the $21^{\text {st }}$ century cannot be achieved under traditional teaching environment alone, therefore, there is a need for integration of active virtual learning environment, which necessitates the introduction of the blended learning model in education training.

\section{REASONS FOR BLENDED LEARNING MODEL IN CONSTRUCTION EDUCATION}

The blended learning model has been identified as the trending education model in the $21^{\text {st }}$ century education model as it has caused a paradigm shift in education training across the globe. The adoption of the modern education model (blended learning) in modern education has been supported by most education stakeholders across the globe due to its deliverables that are evidenced in various field of human education training. The benefits accrued to the use of the modern education model has formed the basis for its wide adoption among education stakeholders. Despite the education model benefits, reasons for its use differ among educators. Different educators adopted the blended learning education model for different reasons in a bid to create the most effective learning environment for students. Its integration into construction education is been driven by reasons which are very germane to students' education training in the construction field.

Eydelman (2013) revealed that one of the reasons for the adoption of the blended learning education model in education training is because of its capacity to induce motivating and friendly learning environment for students. The relevance of blended learning cut across all field of human education training including construction education. The $21^{\text {st }}$ century students are been driven by technology presence. Therefore, the introduction of the blended learning education model will no doubt stimulate students to learn due to their perceived friendliness of the learning environment. Another convincing reason as cited by Pape (2010) for the use of the modern education model across the globe is linked to its ability to cause reduction of time in class teaching in all field human education training. The capacity of the blended learning education model to cause a reduction in time in class during teaching session lies in its effectiveness as an education training model. Its effectiveness is linked to its combined strength in online teaching together with the traditional method face-to-face approach. In construction education training, the use of a blended learning model can reduce class time due to the enhancement of face-to-face teaching method with media presence. Pearcy (2009) also identified the reason for blended learning education model adoption in education training to include its capacity to facilitate interesting teaching and learning during the class session. The capacity of the education model to facilitate interesting class can be linked to the affinity of the modern age students for a technologically driven learning environment. Vernadakis et al. (2011) also revealed that the reason for the blended learning model adoption in education training is aligned to its capacity to create a student-centered learning environment. The blended education model ability to create a learner-centered focus was affirmed by Morgan (2002) as he attested that the model has the 
capacity to shift the education system from a teacher-centered approach to more of studentcentered focus. Under the learner-centered approach, the ability of the students or learners to develop independent learning skills cannot be compromised (Aborisade 2013).

\section{APPRAISAL OF BLENDED LEARNING EDUCATION MODEL}

Ojelabi et al. (2017) asserts that sustainability of education capacity is dependent on the teaching and learning effectiveness. The demand for effectiveness in teaching and learning in the modern age have necessitated for a shift in the existing education model (traditional education style) to a contemporary education model with outcomes, which include learning and innovation, critical thinking and collaboration, and media and technology skills. Hubactova and Semradova (2016) however, opined that blended learning education model is the contemporary education model with capacities to meet the demand of the $21^{\text {st }}$ century. The blended learning education model according to Kosar (2016) is the combination of instructional modalities (e.g., onsite, self-paced learning, and web-based), delivery media (e.g., internet, PowerPoint presentations, textbooks) and instructional methods (e.g., face-to-face or technology-based sessions) and web-based technologies (e.g., wikis, chat rooms, blogs, textbooks, online courses). Garrison and Kanuka (2004) claimed that the hybrid of face-to-face and online technology education model (blended learning model) have the capacity to reinforce both interactive and communicative learning environment critical to expected learning outcomes capable of sustaining education deliverables in the modern age.

\section{RESEARCH METHODOLOGY}

The aim of the study was to assess the uptake of the blended learning model in a higher institution in Nigeria. In a bid to achieve the aim, the study assesses the level of adoption of blended learning tools in construction education and reasons for its implementation in construction education training. Relevant data was sourced from both primary and secondary sources. Primary data was collected with the aid of structured questionnaires administered to academics and students within the in the built environment departments in Covenant University. The sample was selected using purposive sampling technique one of the non-probabilistic techniques. A total of 125 questionnaires were distributed among the academics in the built environment and 100 were retrieved. The questionnaire was divided into three sections: section one examined the characteristics of the respondents, the second section addresses the level of use of blended learning tools and they are placed on the likely scale of $1-5$ which are; $5=$ use very often, $4=$ use often, $3=$ sometimes use, 2 = rarely use, $1=$ not used, and the third section addresses the reasons for implementation of the blended learning tools in construction education using the criteria; $5=$ strongly agree, 4 = agree, $3=$ slightly agree, $2=$ disagree, $1=$ strongly disagree.

\section{ANALYSIS AND RESULT}

Table 1 shows the breakdown of the respondent's characteristics. The respondent's academic status in Table 1 shows that $74 \%$ of the respondents were students while $26 \%$ were lecturers. Also, the gender distribution of the respondent's shows that 54\% represents the male while $46 \%$ represents the female. The breakdown down of the respondent's department shows that Building Technology and Architecture have the highest percentage score with $42 \%$ and $22 \%$ respectively. 


\subsection{Adoption Level of Blended Learning Tools in Construction Education Training}

Table 2 shows the level of adoption of different blended learning tools in construction education training. It was evidenced that the interactive whiteboards and PowerPoint rank very high with mean scores of 4.51 and 4.48 respectively. The next three blended learning tools are often used in construction education training are tablets PCs, learning management system (module) and laptop with the mean score of 4.25, 4.24 and 4.14 respectively. Other blended learning tools, which include video clips, e-mail, audio response system, video conferencing, group collaboration software, web forms and audio file all have a mean score above 3.0, which simply signifies that their use is not that often but sometimes. Web conferencing and mobile phone both have mean score slightly above 2.0 , which signifies that they are rarely used in construction education training.

Table 1. Respondent characteristics.

\begin{tabular}{lcc}
\hline Characteristics & Frequency & Percentage \\
\hline Respondent Academic Status & 26 & 26 \\
Lecturer & 74 & 74 \\
Student & $\mathbf{1 0 0}$ & $\mathbf{1 0 0}$ \\
Total & & \\
Gender & 54 & 54 \\
Male & 46 & 46 \\
Female & $\mathbf{1 0 0}$ & $\mathbf{1 0 0}$ \\
Total & & \\
Respondent Department & 22 & 22 \\
Architecture & 42 & 42 \\
Building Technology & 20 & 20 \\
Estate Management & 16 & 16 \\
Civil Engineering & $\mathbf{1 0 0}$ & $\mathbf{1 0 0}$ \\
Total & & \\
&
\end{tabular}

Table 2. Level of adoption of blended learning tools in construction education.

\begin{tabular}{ccc}
\hline Blended Learning Tools & Mean & Remarks \\
\hline Interactive whiteboards & 4.51 & Use very often \\
PowerPoint & 4.48 & Use often \\
tablets PCs & 4.25 & Use often \\
Learning management & 4.24 & Use often \\
system & 4.14 & Use often \\
Laptop & 3.56 & Use often \\
Video clips & 3.51 & Use often \\
e-mail & 3.50 & Use sometimes \\
Video Conferencing & 3.39 & Use sometimes/use often \\
Audio Response System & 3.38 & Use sometimes/use often \\
Group collaboration software & 3.28 & Use sometimes/use often \\
Web forms & 3.22 & Use sometimes/use often \\
Audio Files & 2.98 & Use rarely/ sometimes use \\
Virtual world & 2.18 & Use rarely/ sometimes use \\
Web conferencing & 2.16 & Use rarely/sometimes use \\
Mobile phone & 1.52 & Rarely use/ never use \\
weblogs &
\end{tabular}




\subsection{Reasons for Blended Learning Tools Adoption in Construction Education}

Findings from the results presented in Table 3 revealed the educationist assessments of the level of agreement to the reasons identified for blended learning tools adoption in construction education are all above mean score of 3.50, which signifies agree on the Likert scale.

Table 3. Reasons for blended learning tools adoption in construction education.

\begin{tabular}{lcc}
\hline Reasons & Mean & Mean \\
\hline Enhance visual aid. & 4.48 & Agree \\
Increase the accessibility of learning materials. & 4.43 & Agree \\
Creates a student-centered learning environment. & 4.40 & Agree \\
Creates interactive learning classroom & 4.39 & Agree \\
Enhance students' knowledge & 4.36 & Agree \\
Support face-face learning approach & 4.35 & Agree \\
Creates a motivating learning environment & 4.29 & Agree \\
Support collaboration & 4.25 & Agree \\
Enhances students learning skills & 4.22 & Agree \\
Creates an interesting lesson & 3.85 & Agree \\
\hline
\end{tabular}

\subsection{Research Hypothesis}

The study hypothesis tested for the significant difference between lecturers and students on the reasons for adopting blended learning tools in construction education is presented in Table 4 using the Mann Whitney $U$ Test. The results revealed that there is no significant difference between the lecturers and the students on the reason for blended learning model adoption at a significant value of 0.205 .

Table 4. Mann Whitney U test statistics.

\begin{tabular}{lc}
\hline & Reasons for Blended Learning Adoption \\
\hline Mann-Whitney U & 802.500 \\
Wilcoxon W & 1153.500 \\
Z & -1.267 \\
Asymp. Sig. (2-tailed) & .205 \\
\hline
\end{tabular}

\section{CONCLUSIONS AND RECOMMENDATIONS}

This study examined the level of adoption of blended learning tools and reasons for its implementation in Covenant University in Nigeria. Findings revealed that the institution affinity for blended learning tools in construction education is fairly good with evidence in the adoption of tools like interactive whiteboards, presentation software (PowerPoint), tablets Pcs, learning management system, laptop and video clip among others in education training. The reasons for its implementation from the study include its capacity to enhance visual aid, increase accessibility of learning materials and student-centered learning environment created among others. The reasons identified in the study for technological tools integration in education training are supported by Eydelman (2013), Pape (2010), Pearcy (2009), and Morgan (2002). However, despite the institution encouraging levels of adoption in some of the ICT tools in education training, the study revealed that its adoption in tools like a virtual world, web conferencing, mobile phones and weblog for teaching are poor. Therefore, the study suggested the need for the 
institution to enhance funding education ICT tools and also encourage the lecturer readiness to the use of a blended learning model through relevant training.

\section{Acknowledgments}

The researchers appreciate the publication support fund given by Covenant University towards the publication of this article.

\section{References}

Aborisade, P. A., Blended Learning in English for Academic Purposes Courses: A Nigerian Case Study, 2013. In B. Tomlinson and C. Whittaker (Eds.), Blended Learning in English Language Teaching: Course Design and Implementation. London British Council, UK.

Afolabi, A., Ojelabi, R., Oyeyipo, O., Tunji-Olayeni, P., Omuh, I., and Amusan, L., Integrating Software Development Courses in The Construction Curriculum, Turkish Online Journal of Education Technology, Special Issue, 2017.

Buran, A., and Evseeva, A., Prospects of Blended Learning Implementation at Technical University, Procedia-Social and Behavioral Sciences, 177-18, 2015.

Coiro, J., Reading Comprehension on the Internet: Expanding Our Understanding of Reading Comprehension to Encompass New Literacies, The Reading Teacher, 56, 448-464, 2003.

Culatta, R., Distance Learning. Innovative Learning, 2011. Retrieved from http://innovativelearning.com/online-learning/distance_learning.html in July 2018.

Eydelman, N., A Blended English as A Foreign Language Academic Writing Course, 2013. In B. T. C. Whittaker (Ed.), Blended Learning in English Language Teaching: Course Design and Implementation. UK: London British Council.

Garrison, D. R., and Kanuka, H., Blended Learning: Uncovering Its Transformative Potential in Higher Education, The Internet and Higher Education, 7, 95-105, 2004.

Hubactova, S., and Semradova, I., Evaluation of Blended Learning, Procedia-Social Behavioral Sciences, 217, 551-557, 2016.

Kosar, G., A Study of EFL Instructors, Perceptions of Blended Learning, Procedia-Social and Behavioral Sciences, 232, 736-744, 2016.

Mason, R., and Rennie F., E-Learning: The Key Concepts, London: Routledge, 2006.

Matukhin, D., and Zhitkova, E., Implementing Blended Learning Technology in Higher Professional Education, Procedia-Social Behavioral Sciences, 2016, 183-188, 2015.

Morgan, K. R., Blended Learning: A Strategic Action Plan for A New Campus, University of Central Florida, 2002.

Ojelabi, R., Afolabi, A., Tunji-Olayeni, P., Amusan, L., and Omuh, I., Learning Adequacy of Nigerian Tertiary Educational System for Sustainable Built Environmental Course, Turkish Online Journal of Education, Special Issue 2017.

Pape, L., Blended Teaching and Learning. American Association of School Administrators, 2010. Retrieved from http://facultycenter.ischool.syr.edu/files/2012/02/blended-learning-and-teaching.pdf in June, 2018.

Pearcy, A. G., Finding the Perfect Blend: A Comparative Study of Online, Face-To-Face, and Blended Instruction, $\mathrm{PhD}$ Thesis, University of North Texas, 2009. Retrieved from http://search.proquest.com/docview/304963133?accountid =4488, on June, 2018.

Tapscott, D., Grown Up Digital: How The Net Generation is Changing Your World, New York: McGrawHill, 2008.

Vernadakis, N., Giannousi, M., Derri, V., Michalopoulos, M., and Kioumourtzoglou, English. The Impact of Blended and Traditional Instruction in Students' Performance, Procedia Technology, 1, 439-443, 2011. 